\title{
Revisiting Post-Election Violence
}

\section{Hervé Maupeu}

\section{(2) OpenEdition}

\section{Journals}

Electronic version

URL: https://journals.openedition.org/eastafrica/719

DOI: 10.4000/eastafrica.719

ISSN: 2790-1076

\section{Publisher}

IFRA - Institut Français de Recherche en Afrique

\section{Printed version}

Date of publication: 1 April 2008

Number of pages: 193-230

ISSN: 2071-7245

\section{Electronic reference}

Hervé Maupeu, "Revisiting Post-Election Violence", Les Cahiers d'Afrique de l'Est / The East African Review [Online], 38 | 2008, Online since 18 July 2019, connection on 09 December 2021. URL: http:// journals.openedition.org/eastafrica/719 ; DOl: https://doi.org/10.4000/eastafrica.719

This text was automatically generated on 9 December 2021.

Les Cahiers d'Afrique de l'Est / The East African Review 


\title{
Revisiting Post-Election Violence
}

\author{
Hervé Maupeu
}

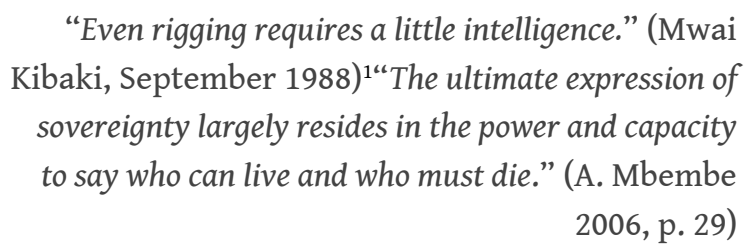

For some time now, optimism over the third wave of democratization has died out. An increasing number of authors remind us of the adverse effects of electoral democracies that increased in the beginning of the 1990s. At the time, many hoped that a combination of development and democracy, along with liberalism would lead to peace and general prosperity. In many countries, however, it is violence, ethnic cleansing and authoritarian reactions that seem to be the order of the day.

2 The conflagration of violence that Kenya experienced between December 2007 and March 2008 was surprising, especially because Kenyan democracy was viewed as the most successful in the region, particularly after the 2002 political transition. Moreover, Kenya and Tanzania were the only countries in East Africa not to have undergone any major armed conflict. At least they had not experienced devastating civil war like the rest of their neighbours. Kenya's political culture had certainly for a long time been more violent than Tanzania's. Nevertheless, social violence had escalated in Kenya since the return of multi-party politics and the spread of non-regulated market economy. Thus, Amy Chua's general contention that "the worldwide spread of the free market and democracy is an important cause of ethnic violence, a factor that is aggravating hate between communities throughout the nonwestern world" 2 seems to be a convincing illustration in contemporary Kenya. This view, largely shared by anthropologists such as Arjun Appadurai and journalists such as Robert D. Kaplan, ${ }^{3}$ compels us to think about the particular nature of capitalism in this part of Africa as well as the form of democracy that has lately established itself in order to understand the mechanisms that lead to violence. In this case there were serious repercussions (close to 1,500 deaths and 300,000 displaced persons), commonly portrayed as pitting ethnic communities against each other. 
3 The 2007-2008 electoral violence will be discussed by first introducing the main analytical paradigms that gave rise to fear of political violence in the multi-party era in Kenya. This means focusing on the political psyche in one part of Kenya, the Rift Valley. The land policies established by the colonial and post-colonial systems under regimes that employed different strategies created dynamics of exclusion, which are expressed within a context of electoral democracy and capitalism among cronies. Until the last general elections, the deadly effects of this ethno-nationalism had been largely confined to the Rift Valley. However, these mechanisms now tend to contaminate the whole country, notably through inter-community relations in towns.

\section{Paradigms for analysing the 2008 election violence}

4 Three months after the crisis began many experts on Kenyan politics had already made analytical arguments which will probably be analysed in future academic papers. The speed with which views were expressed is unusual in this field. ${ }^{4}$ It certainly corresponds to advancement in political science that is adapting to new forms of communication. The various types of media seek insight from researchers and internet websites, particularly current platforms that make more complex expression possible than interviews with journalists. This is the particularly the case in Open Democracy that seems to be the website of choice for most Kenyan experts.

5 The interpretation of the Kenyan crisis was varied, questioning the majority syndrome of the Western media that was unanimous in a voyeuristic fascination they portrayed as irrational barbarism. However, as explained by Madeleine Bunting, the illustrious Guardian columnist, "The violence in Kenya may be atrocious, but it is not "unfounded savagery." ${ }^{5}$ The tendency not to search for the social (or historical) causes of this violence would be less attributable to a certain level of intellectual laziness than to unconscious racist clichés based on how the North views countries in the South. Academic analyses inoculate us from this danger. Obviously, their approaches vary but all things considered, they are mostly complementary.

6 The election violence led to several studies in Kenya. These were mostly carried out by human rights NGOs, which are very well-established in the country, and had interest in the topic. From the social studies point of view, they made the notion of "election violence" appears to be an operational concept, especially when they defined it precisely and in a way that made relevant analysis possible. The Central Depository Unit's (CDU) definition is one of the most interesting approaches. It views electoral violence as

Any act or set of acts that harm or threatens to harm individuals or groups of people, to cause some damage to property; if the acts or the sets of acts are aimed at or have the effect of manipulation on the choice or the election results. The damage caused can be physical, psychological or both. Election violence can occur before, during or after an election. ${ }^{6}$

7 In their approach, these activists do not distinguish pre-election violence from postelection violence. Their definition is based on their observation that the cycle of political violence often begins before elections and does not end after that, even though the person behind the problem has been elected. This leads to the CDU's assertion that: "Elections not only concern the campaigns and the polling day alone. The electoral process is a cycle that lasts the whole period of a government's stay in power." "This extensive view of 
election violence is highly applicable to Kenya. Nevertheless, it does not mean confusing political violence and election violence as the same concept. A study of the tensions at the beginning of 2008 will reveal that some conflicts were rekindled during the elections but the issues had nothing to do with the polls. The number of deaths in these areas and during the election period is substantially the same as that registered over the past few years.

The human rights NGOs also demonstrated the wide variety of election violence that are expressed in various ways such as

... murders, murder attempts, confinement, aggression, threats of violence, torture, arson, rape, sexual harassment, abduction, obstruction, looting, threats, intimidation, hate speech and slander. Others are: insults, political treachery, embezzlement, destruction of property, damage to property, economic oppression, sabotage, evictions, closure of the political party offices or campaign offices, violent disruption of public rallies or campaign meetings, including sudden change of venues of such meeting by the authorities. ${ }^{8}$

Beyond simply showing the repertoire of practices, this list also reveals the multiplicity of methods used by politicians.

NGO analyses are based on an analytical focus that is first and foremost neoinstitutionalist in nature. They have a pragmatic approach in the sense that they constitute "applied" social studies. This makes them carry out research on the institutions that are important social actors because their objective is to suggest changes and if possible, improvements in the functioning of these institutions. In this sense, these advocates (they are often law graduates) do not have a strictly normative approach even though they manage to come up with recommendations that are mainly (but not only) legal. Looking at the 2008 political violence, the interest in using their approach becomes clear. Their work on the 2002 elections heralded difficulties related to the 2007 elections. The CDU emphasized that institutional inconsistencies of political parties which are basically mere election machines activated during campaigns, creates favourable conditions to primary elections that are often chaotic and violent. It denounced the ECK's modus operandi, showing clearly that it could not be relied upon to organize the elections. ${ }^{9}$ In December 2007, the rigging took place in ECK offices. The CDU also highlighted the autocratic culture within the Kenya Police, which lacks professionalism and is propped up by a legal framework that does not define election violence. Election violence is therefore a matter of the general law, particularly the general penal code, which leaves a lot of leeway (and room for interpretation) for the security forces.

11 Nevertheless, the NGOs' neo-institutionalism perhaps assigns too much influence to the law than it really has. This voluntarism, believing in the impact of the government on the rule of law, is not necessarily naive. However, it reduces the analytical focus because the institutions do not explain the whole crisis and will not be able to resolve the observed problems on their own. This is insofar as Kenya is a political system where the State still has weak institutions (even though it is the most structured and effective State in the region). The analysts did not foresee the crisis that followed the elections of 2007. The failure of the political transition was surprising because it was thought (or one would have wanted to believe) that the political class had really been converted to a culture of democracy. The intensity of the violence also took observers by surprise. Political experts now focus on the existing dynamics that were sometimes barely visible but 
which facilitated or precipitated the crisis. The NGO analyses of the election violence show this approach. Nevertheless, until specialists on Kenya who have commented on the situation show that, even amidst the hue and cry over the crisis, the varied approaches could prove to be illuminating.

First, there are those who point to external explanations and in particular those that favour the view of the white man's guilt. Caroline Elkins ${ }^{10}$ states that "whereas hundreds of thousands of Kenyans fled their homes and hundreds died, the Great Britain takes part of the blame for its imperialist policies." She thus revisits the views she held during debate on her work on the repression of Mau Mau ${ }^{11}$ fighters. According to her, the colonial government left a legacy of an autocratic political culture, which is the direct cause of the current ethnic tension because it fossilized heterogeneous groups of individuals in closed ethnic communities and pitted them against each other due to its divide and rule policies. Her analysis points out the carving out of the electoral constituencies along ethnic lines and that the political class is a direct legacy of the colonial era. This has been perfected through the government's approach. Nevertheless, C. Elkins analyses largely draw from the Anglo-Saxon debates on post-colonial issues. Her views probably make it possible to understand certain dynamics of Western imperialism and lead the Northern States to assume their historicity and perhaps the debts incurred in relation to the South, as well as to understand the particularities of contemporary African States.

14 Michael Holman ${ }^{12}$ holds a view close to C. Elkins'. He questions the Western countries and NGOs which all along supported M. Kibaki's government when financial scandals were exposed and evidence of high-level corruption had been gathered. Thus, they approved the ills of a regime that led to the major crisis that Kenya is currently experiencing. The issue of responsibility should be raised. Wanyama Masinde ${ }^{13}$ has already published reflections on possible ways of resolving the crisis. According to him, the management of the postcrisis period demands a search for those responsible for the crisis and legal action against the guilty parties who are part and parcel of the Kenyan political class. He once again goes through an analysis of the country's internal dynamics without hiding behind exogenous causes.

Gérard Prunier ${ }^{14}$ develops a framework of complex analysis that begins by highlighting the Kenyatta era (1963-1978) as the matrix of the national political system that M. Kibaki largely reactivated following the long interlude of the Moi era (1978-2002).

From Kenyatta's time, the deal was simple: the Kikuyu and their small sub-tribes, after having reached an agreement with the minority ethnic groups, took control of everything. The Luos, who sought to modify this order of things, were marginalized, while the prudent Luhyias watched.

G. Prunier draws attention to the fact that the Kibaki team, which was elected to implement the far-reaching reforms, principally crystallized the idea that it was seeking to first Kikuyunise the State and did not aspire to equitably share the fruits of growth. This led to a more anti-establishment than anti-Kikuyu majority vote during the elections. The analysis of the socio-political context leads him to evaluate the nature of the outbreak of violence that followed the vote: "political violence should be considered both ethnic and socio-economic." In fact, the diagnosis made by all other experts on Kenyan states this claim while highlighting the two dimensions, and demonstrating how they function, which G. Prunier hardly done.

Aggrey Omondi ${ }^{15}$ says: 
... the cause of the problem is neither tribalism nor politics (whose role is solely incitement), but rather a long simmering history of glaring poverty and despair, which has now reached a boiling point with a generation of young Kenyans to whom basic opportunities have been denied.

18 His analysis, rather brief in some aspects, has the merit of emphasizing the role of the youth but even then, he only views one part of problem when he emphasizes that young men found an opportunity to express their economic frustrations through the crisis. These young people must first and foremost be perceived as social cadets who hold important means of pressure through the militias that organize them.

The last open forum on the Kenyan crisis highlighted the ills of ethnicity. Angelique Haugerud $^{16}$ believes that political ethnicity does not determine political development but constitutes a contingency of uncertainties. By this she means that the content of ethnicities can evolve. She takes a peek into the future by expressing the wish for these identities to depend more on the reciprocities of everyday life, which will make it a collaborative issue rather than pit two groups against each other. However, some negative dynamics weigh against and impede this evolution: the divide between the political elite and ordinary citizens, the inequalities between those who still have a roof over their heads and those who have been dispossessed, and finally, the tension between what can qualify as electoral democracy and what corresponds to substantial democracy.

John Lonsdale ${ }^{17}$ bases his appreciation of the Kenyan crisis on a very classic analysis of the structural functioning of political competition. Power-sharing of State authority is governed by rivalries between ethnic groups and within the ethnic entities through a vision of responsibility on the part of elected leaders in relation to the community. These two dynamics are complementary. However, this extractive approach to politics, which Jomo Kenyatta broke, increased the difficulties the Moi regime faced and which the M. Kibaki team must now manage. Lonsdale explains to us this new equation with his habitual finesse:

The fierceness of the competition for sharing of State power became more intense with time - as far as the population increased, and while the abundant showers of opportunities in post-colonial Africanisation had long stopped, the conditions of exchange for primary needs had proved to be bitter. It would have been quite easy for Kenyatta to guarantee that everyone has their turn 'to eat' through ethnic coalitions on which parliamentary majority depended.

21 It was more difficult for Moi. As the list of political interests grew, it became more tempting to attract and to reward one's ethnic supporters with opportunities to grab resources at the expense of those who had now become tribal rivals for land, urban property, or the small enterprises. With every "bought" election, anger mounted among Kenyan citizens to the point that they piled pressure for constitutional change that would have strengthened parliament, to the detriment of the presidency.

22 Thus, the current crisis is a result of the ills of "politicized tribalism," the principal means of winning post-colonial State power, which is less viable than before but remains the most important means to riches.

23 It is observed that these very first studies on the Kenyan crisis principally aim to understand the causes of tension, particularly historical dynamics that led to the current situation. In the meantime, these researchers are not interested in the forms in which the violence manifested itself, the protagonists or in its geographical spread. Besides, the factors-especially the economic ones-behind the outbreak of violence 
have hardly been analyzed, as if it was the exclusive duty of human rights NGOs, which have already published voluminous reports. ${ }^{18}$

\title{
Factors behind the violent protests over official election results
}

\begin{abstract}
elections have been contested by losers. Nevertheless, these accusations of rigging did not degenerate into an outbreak of large- scale violence like in 2007-2008. It is true the 1992 and 1997 elections led to post-election violence, but there were never perceived to have characteristics of a civil war. The nation and the State did not seem to be in contention. How different are the 2007 conditions from those of 1992 and 1997 ?
\end{abstract}

\section{Elections under high tension}

Electoral fraud has been widely practiced since the introduction of elections in the colonial era. The return of multi-party politics enhanced the chances of rigging the outcome of elections. In this context, between the opposition and the majority, those in government have a lot more means and opportunities at their disposal, since they control the local administration as well as the police. The 2007 election clearly indicated the advantage that the incumbent has. Thus, all the bodies that monitored the elections showed that some rigging affected ODM (Orange Democratic Movement) areas, but the rigging was apparently much more massive in constituencies where PNU (Party of National Unity) had the upper hand. The ECK staff seems to have played an important role in this rigging, both at local and national level. The commissioners appointed in 2007 by the President without consulting the opposition, as was the practice since 1997, were hence accused of abuse of office.

These excesses were nothing new. International observers who monitored the 1992 elections considered them marred by numerous intimidations and rigging. In 1997, European observers, before assessing the fairness of the election, were obliged to reconsider their stand to enable Northern States endorse the official results. After these two elections, losers denounced rigging that led to fraudulent results.

In 1992, the opposition garnered more votes than the incumbent but, since they were divided in the struggle, President Moi and KANU (Kenya African National Union) garnered a higher number of votes. KANU managed to unite the small ethnic groups against the threat of a dictatorship from a possible alliance between the Luo (represented in the presidential election by Oginga Odinga) and the Kikuyu, who had two candidates-Kenneth Matiba and M. Kibaki. After an election marred by numerous cases of fraud, the three opposition leaders tried to set in motion what they called "unity in defeat." They intended to contest the election results through mass action but their disagreements re-emerged and the rallies ended, especially because 0 . Odinga quickly negotiated a cooperation mechanism with the government. Legal petitions were also launched but they were pointless in a country where judges are on the government's payroll (or of the rich). After a few weeks, the challenge to the election results died out and losers sought to prepare themselves for the next elections. Indeed, the political system, especially parliament was so restricted that the opposition could 
hardly be accorded any role. The practice was such that the winner took everything, leaving the loser with nothing.

Influenced by the civil society, particularly the lawyers in the Law Society Kenya and human rights NGOs, the opposition politicians were convinced that the Moi regime could not be changed without constitutional review. The incumbent had too much power leverage and influence that it made competition unequal, and all the candidates did not compete on a level playing field. From 1993, an active minority of lawyers, with massive support from Catholic and Anglican bishops, held public debates on the desired content of the next constitution. During this period, Christian institutions took in the streams of persons who had been displaced following ethnic cleansing in the Rift Valley, and this deeply changed relations with the political leadership. Leading clergy expected constructive criticism of the regime from lawyers, who, on the one hand, explained the institutional shortcomings that led to such dramatic autocratic ills, and on the other, recommended reforms. Moreover, leaders of the mainstream churches were unhappy with the political class. They thought the opposition was locked in ego wars and did not particularly consider them as sincere democrats. Thus, between 1993 and 1996, political professionals took little interest in debates on constitutional reform. But at the beginning of 1997, just before the election campaigns, opposition politicians plunged into the constitutional reform movement because they saw that the civil society could mobilize crowds. In reality, the protests led by groups of lawyers were more to the point than the rhetoric of elected leaders which offered nothing new. Residents of big towns were convinced long before the politicians understood that institutions count and that change would follow suit. In 1997, the regime conceded cosmetic constitutional reforms that did not really change the power imbalance. Besides, the opposition proved unable to unite just as in 1992, facilitating the incumbent's victory.

Once again, opposition leaders rejected the election results. In his biography of Raila Odinga, Babafemi A. Badejo gives a rather detailed account of the weeks that followed the 1997 elections..$^{19}$ One of the presidential candidates, Michael Wamalwa, did not join the rest of the opposition in taking action against the government. He immediately accepted the official results. M. Kibaki, Charity Ngilu and R. Odinga initially planned to mobilize supporters to disrupt the swearing in of the President. However, the plan did not work. M. Kibaki made inflammatory statements in the media but no action followed, and on 6 January, Odinga recognized President Moi's re-election. He particularly suggested ways of cooperating with the regime and led his party LDP into government, then went ahead to merge it with KANU. Rather than protest against the government, he cynically opted to collaborate with the incumbent to promote his ideas on necessary constitutional reform from within the government. Finally, the contentious results of the 1997 elections were accepted by an opposition that was so increasingly frustrated that it found itself in a position of helplessness in the face of targeted government-orchestrated violence. Thus, militias basically attacked areas associated with candidates who intended to petition the official verdict of the elections.

The 2002 elections took place with a radically renewed party system. KANU imploded, thus facilitating unity of a large opposition. This overturned political landscape was mostly due to activism by Raila Odinga, who jumped off the KANU ship a few weeks before the elections. He joined the opposition, which won the election with a big margin. Uhuru Kenyatta, the KANU candidate, quickly conceded defeat, which was 
particularly significant for both the presidential and legislative elections. Obviously, elections are contested only when the results are controversial and the race between the two camps was very tight.

31 This was the case in 2007. But why was R. Odinga, the opposition leader who so easily conceded defeat in 1992 and 1997, so pugnacious and reluctant to accept official results in 2007? Why did he validate such a violent protest against the government?

\section{The particularity of the 2007 elections}

Once again, the party system had changed enormously since 2002. The development of party alliances as well as changes in organization of some parties makes it easy to understand that in 2007, the opposition had more means and opportunities to resort to violence (if the leaders opted for this strategy). First, the ODM, which crystallized after the 2005 referendum, is commonly viewed in Kenya as an agreement to join majority forces between the Luos, the Luhyas and the Kalenjins. Most ODM Kalenjin leaders built up a large part of their political career within KANU during the Moi era. In the 1990s, they often participated in the two waves of ethnic cleaning, without necessarily being the brains behind it. ${ }^{20}$ They were part of a regional political system that unanimously rejected the presence of people perceived as non-natives.

This vision of political life has until now been confined to the Rift Valley, but in this region, it permeates numerous categories of the population. This ethnic nationalism of exclusion is not only a matter of manipulation by the elite. It is an ideology that now involves a lot of people. In the beginning of the 1990s, the initial research on ethnic massacres in the Rift Valley blamed gangs of youth manipulated by politicians. The populations on the ground did not seem to directly participate in the killings. On the contrary, the early 2008 ethnic violence tried to involve as many people as possible.

The Luo and Luhya political forces also had great potential to mobilize for violence. R. Odinga attempted to build a party with the characteristics of a "movement" based on the Ugandan model invented by Yoweri Museveni or the Rwandan model as structured by Paul Kagame. The Kenyan context and the need to build coalitions limited R. Odinga's ambitions. Nevertheless, this inspiration existed in a more systematic and structural use of youths than in other Kenyan parties. Thus, the youth in his camp were organized in paramilitary units. Parallel with these official structures, with the help of Luo personalities, the party funded militias of vigilantes that patrolled districts in all big cities in the country where the Luo are dominant. They were also used to control the votes of people living in the area. In 2002, R. Odinga had already set in motion this electoral strategy and it had begun creating tension with other vigilante groups. ${ }^{21}$ In 2007, this unique network of militias in the big cities made it possible to immediately react to the announcement of election results that were considered rigged. However, it is impossible to blame them for all the ethnic cleansing that occurred in the slums of Nairobi.

The Luo politicians were not the only godfathers of the militias. Among the leaders of ODM, William Ruto was one of the founders of the Youth of KANU '92, and one of the sponsors of Kalenjin warriors who organized the massacres perpetrated in Eldoret South in 1992-1993. Fred Gumo, the Westlands MP, for a long time controlled the Jeshi la Mzee. W. Ruto and F. Gumo were part of the small minority of big men who had the means to permanently have militias at their disposal. The other politicians only 
recruited these groups of youth during the election period to ensure security at their rallies and their movement in the constituency. Thus, the culture of militias permeated the political class in the two camps. However, the incumbent or at least top government leadership spent a lot of energy in 2007 trying to weaken the main force of youths in their ethnic group. They actually persecuted Mungiki, thinking that they would not need its services like they had during previous elections, since they controlled the police force from 2002. This calculation proved to be wrong because their community was less organized to counter the violence that broke out shortly after the election results were announced.

The opposition therefore had a vast repertoire of options in 2007 as opposed to the previous elections. Resorting to violence was one of the options at its disposal. In early January 2008, Martha Wangari Karua, Minister of Justice and Constitutional Affairs, and close advisor to the head of state admitted during an interview with $\mathrm{BBC}$ programme HardTalk that the government had predicted that ODM "could plan violence if they lost" but she expressed surprise at the "magnitude" of the reaction and that it amounted to "ethnic cleansing." The incumbent thought that State monopoly of power would protect them and would enable them to act with impunity. They had underestimated the new opposition forces. This was particularly manifest in the Rift Valley Province.

\section{Election violence in the Rift Valley}

All analysts stressed that election violence is a recurrent problem in Kenya's democratization process. It is intimately linked to land policies of the post-colonial State, particularly those of the first president, J. Kenyatta. He allocated large tracts of land in the Rift Valley ${ }^{22}$ to members of his ethnic group, the Kikuyu, who have since been considered as intruders. Nevertheless, the presence in the Rift Valley of the Kikuyu, alongside the Kisii, the Luo and the Luhya is not a recipe for violence until tension is sparked off by State actions, with the behaviour of the administrators often construed as provocation. The other necessary ingredient is cynicism of some politicians who fuel the resentment and finance gangs that are ready to slaughter the targeted people. This section will determine the structural dynamics that fuelled election violence both before and after the elections.

\section{Tension zones}

The 2007 election campaigns have currently been portrayed as having been more violent than the 2002 campaigns, which were the most peaceful of the multi-party era. The Kenya National Commission on Human Rights (KNCHR) ${ }^{23}$ reports showed that about 70 people died from July, whereas in 2002, 325 Kenyans lost their lives in political tension. To put the KNCHR figures in perspective, it should be remembered that it does not use the same criteria used by other human rights NGOs in assessing election violence. It only keeps records of violence that occurs around election-linked events (rallies, demonstrations, primaries...). This very narrow definition excludes the most heinous violence of the period that precedes the elections. Thus, the very high numbers of deaths in Mount Elgon (close to 600 and 150,000 displaced persons since the end of 2006) are not accounted for. Some 500 youths killed in 2007 by the police in the fight 
against Mungiki as well as scores of murders committed by members of this militia group are not part of the KNCHR analysis.

Regardless of these two large tension zones where conflict was already intense throughout 2007, there were visible crisis areas where violence started as part of the election campaigns before really exploding after the elections. This geography of massacres is familiar as it is similar to the ethnic cleansing perpetrated during the 1992 and 1997 elections.

Indeed, the 2007 election campaigns reactivated the usual tension areas in the Rift Valley, some of them having been in existence since the Mau Mau crisis in the 1950s; some even echoed the anti-colonial uprisings in the 1920s. This region is popularly known as the smouldering cauldron of Kenyan politics. It would be perhaps more relevant to see it as the black box of the political system because the problems facing this zone are at a national scale. However, from a political analysis perspective, it is difficult to view the Rift Valley Province as one whole. That is what John O. Oucho ${ }^{24}$ does when he stresses that the province experienced the highest population growth rate in the country (after Nairobi) due to massive immigration. He recalls that the Kikuyu had the highest amount of investment in the region and that their dynamism made it possible to develop proximity trade as well as the agricultural sector. He identifies the general circumstances that encourage aggressiveness of people that consider themselves natives of the region. However, this large area of focus not makes it no easier to understand why conflicts break out precisely at a given period and in specific places. Some areas seem more conducive for these types of political strategies. Hence, it is worthwhile (at least concerning our subject) to begin from the standpoint that the Rift Valley is not a homogeneous province, neither from the cultural point of view nor in the political arena. It has to be seen as a mosaic. Thus, the national politics are diffracted or articulated in this zone according to very specific grounds and localized relationships. To illustrate this, it is necessary to highlight one area of tension, Molo. This zone is only one of the hot points in the Rift Valley because in 2007, relatively serious violence was also recorded in Laikipia, Trans Nzoia, Narok, Turkana South, Baringo, West Pokot, Trans Mara and Kuria districts.

\section{The case of Molo}

41 Molo is situated in the heart of the Rift Valley Province. It is one of the main places dominated by Kikuyu politics, which is often mistaken to be confined to Central Province. This mistaken belief is due to long-standing reasons. It is particularly the Olenguruone ${ }^{25}$ crisis that captured the political imagination of this political field, at least from the Kikuyu point of view. In 1939, the state bought 52,000 acres in Olenguruone, land that was at the time part of the Maasai Land Unit. This land was redistributed to squatters on white farms, who had been rendered less as a result of mechanization. It was also at this time when families that had lost land in the Kiambu region following the expansion of white farms, were compensated. Those Kikuyu that had settled on neighbouring Maasai land were relocated to this new site. This colonial programme of settling farmers caused great frustrations. The administration refused to issue title deeds. The farmers found themselves left only with tenant farming rights (ahoi). Given the type of farming they practiced the acreage of land they were allocated was insufficient to live on. In fact, the administration sought to impose on them some 
crop farming methods that were supposed to avert erosion, but the Kikuyus stubbornly refused to apply them. From then on, the families never managed to live sufficiently off the land. This led to the colonial authorities gradually evicting these families, who were then transferred to the Kamba region in the 1950s. It was a radical means of countering the deep politicization and mobilization of Olenguruone inhabitants. Indeed, since 1943-1944, most Olenguruone inhabitants took a unity and struggle oath, which gradually spread to squatters of the white farms of the Rift Valley and to the people of Kiambu South. Thus, mobilization among these farmers is commonly believed to be one of the main beginnings of the Mau Mau ${ }^{26}$ crisis. The memory of this struggle still lives on. Several songs sung by the Mungiki, a neo-traditional Kikuyu sect that unites a number of militias, speak of this crisis and honour the fight by these ancestors. In reality, Olenguruone has for over half a century symbolized what the Kikuyu consider the injustice of land ownership as imposed by the State. These Kikuyu were denied the basic right to achievement as a Kikuyu man-that of owning land on which to exploit his talent as he so wishes without outside interference. They were also stopped from enjoying clear rights on their land. Thus, Olenguruone is perceived as a story of multiple political obstacles that the State placed on their desire to live off farming. It explains the numerous failures of plans to resettle landless peasants or those who had been evicted.

Olenguruone did not stop the Kikuyu from returning to the Molo area. For a number of families from Central Province, national independence meant opening internal borders so that these peasants could try their luck where land could be bought. The Rift Valley was thus the land of opportunity at the time since the Whites, who controlled a good part of the land, had left the country. It is influential people, particularly politicians, who benefited from the manna but in Molo the land was not very fertile. It attracted only small-scale farmers, who mainly cultivated pyrethrum in these high altitude areas (approx. 2,500 metres above sea level). When multi-party politics resumed, this immigration, some cases of which were old, was perceived by some quarters as intolerable. In 1992, the first ethnic cleansing began but in this region where the Kikuyu were very politically aware, this technique actually led to the election of good people. In order to put an end to the excesses and pacify the region, the area's political leader, John Njenga Mungai negotiated with the government and crossed the KANU rubicon. In 1997, he lost his seat-the Kikuyu voters blamed him for compromising. Dickson Kihika Kimani was elected with $73 \%$ of the vote on a DP (Democratic Party, M. Kibaki's party) ticket just when violence was resuming.

Following their failure in 1992, Kalenjin leaders managed to hive off a section of Molo constituency in 1996, which became a new entity that would be a "KANU zone." Kuresoi thus annexed Olenguruone that had been "cleansed" of Kikuyu farmers. Some came back but most of the land had been repossessed at throw-away prices by the influential people. This frustrated the landless Kalenjins. In 1997, Kuresoi was less affected by massacres than Molo because the ethnic demography had already changed and the whole region was traumatized by the killings carried out by their neighbours. Added to this was the economic depression that had persisted following the initial unrests of 1992 (several commercial sectors died out with the departure of the Kikuyu). In 2002, KANU won back the constituency with only $47.5 \%$ of the votes. Mburu Mungai got all the Kikuyu votes (21\%) while the other five Kalenjin candidates were an indication of dissatisfaction of voters. The 2007 elections therefore promised to be difficult and 
ethnic cleansing was in the offing. By the end of October, some Kikuyu farms had been burnt and people killed. The escalation of violence was swift as the Kikuyu retaliated and killed several Kalenjins. In the tension that ensued, some Kisii families were also slaughtered. Within three months, close to 25 people had been killed and 16,000 displaced (according to Red Cross figures). All human rights organizations that carried out investigations in the area accused two politicians. Fingers were pointed at the outgoing MP, Moses Cheboi, who after losing the primaries, sought to defend his seat paradoxically under the banner of a dominantly Kikuyu party, Safina. His main competitor, Zakayo Cheruiyot (ODM), who went on to win the elections, was also said to have bankrolled the political violence during this period.

\section{The Mau Forest}

Forest. This massive highland (covering close to 400,000 ha; $36 \%$ of the country's forest cover) is one of the important areas in Kenyan politics. Multiple political problems adhere to this area but the bone of contention is due to the fact that several communities are fighting to enjoy this very fertile land. The Kikuyu, especially those who were internally displaced the 1990s, see in it uncultivated areas; the Maasais do not want to lose their political influence over the area as they had occupied it for a long time; the Kipsigis to the west and the Kisiis did not want to be left out in the sharing of the spoils; finally, throughout the $20^{\text {th }}$ century, the Ogiek (earlier referred to as Dorobo), who were determined to live exclusively in forests were a pretext for tension with the State and between the communities in the area. In the last few years, disputes have focused on the State plans to resettle the Ogiek, which has led to mismanagement and land grabbing by influential people and politicians.

First is Likia, which is situated in Mauche Division of Nakuru District. For two years, it has been at the centre of violence between Kalenjin and Kikuyu militias. In 1997, 1,605 acres of forest land was allocated to 318 Kalenjin families. The owners are generally absent and they cultivate the land through relatives. Since the beginning of M. Kibaki's presidency, families of internally displaced Kikuyu in the 1990s have been squatting on parcels of land neighbouring the forest on the grounds that if Kalenjins could deforest, they in turn, could also illegally settle. In 2003, Lands Minister Amos Kimunya declared that all forest inhabitants were illegally occupying public land. The Kalenjin families and the Kikuyu squatters were asked to leave. Negotiations with the government attempted to find solutions. In the beginning of 2006, Kalenjin militias attacked the neighbouring Kikuyu squatters. Two months later, the police expelled the two communities. Since then, the clashes have increased with the former occupants determined to come back.

The second hot spot is eastern Mau. Towards the end of the 1990s, 24,000 ha of highly fertile volcanic land were carved out of the forested area ${ }^{27}$ and close to 28,000 people were settled on these plateaux. In 2001, the State degazetted this part of the forest, officially declaring that it was no longer forestland. But the number of farmers grew too rapidly and their farming methods endangered the ecological balance of these hills, which are the source of the rivers that flow into Lake Nakuru ${ }^{28}$. The government sought 
to control this situation and this caused tension, leading to many deaths over several years.

The third area is the Maasai Mau Forest, which experienced recurrent violence. In 2005, close to 10,000 people (2,750 families) were evicted by the police. The authorities destroyed not only houses but also community facilities (schools, churches, clinics). The police engaged in excesses that led to the explosion of the political situation.

\section{Fragile policy lines}

Thus, it was easy to believe that the Kibaki regime was determined to control the land situation in the country and put an end to the illegal occupation of public land. However, this policy became untenable during the electoral campaign period. In 2007, the government made some progress on its policy regarding forest squatters and it allowed the evictees to return. Weeks before the primaries, the ban on the "shamba system" was lifted. As a result, close to 10,500 people returned to Mau Forest. This directly conflicted with the Maasai interests, made the Kipsigis jealous and disrupted the Ogiek lifestyle. Some candidates in the elections did not particularly appreciate this influx of people, which was hardly in their favour. It was impossible to rule out the recurrence of political violence under such circumstances. In Molo District alone, a variety of tension areas can be identified. They are supported by national dynamics (especially through State policies) and by very local and often old-fashioned thinking. After the 2007 election results were announced, these conflict spots, where election campaigns proved to be particularly violent, experienced violence on a more vicious scale and tension reached its peak.

Obviously there were massacres in many other places from the end of 2007, but even then, violence did not break out just anywhere. Shortly after the beginning of the crisis, between 27 December 2007 and 3 January 2008, UNOSAT published satellite photos of fires in the Eldoret area. ${ }^{29}$ During this first week, the most intense fires were reported on 1 January. A look at these documents showed that the violence was essentially concentrated in two places, one of which is well known: Burnt Forest. In 1992, the first ethnic cleansing of the multi-party era took place here. It targeted a Kikuyu settlement set up shortly after independence on land formerly belonging to British farmers.

The numerous killings in Kalenjin areas were the result of ethno- nationalism which radically shuns people perceived as non-natives who are out to loot wealth that belongs to them. This ideology has recently been reinforced by two dynamics. The first is linked to the policies implemented by the Kibaki regime on internally displaced persons, who were victims of various waves of inter-ethnic violence. In 2004, United Nations agencies estimated the number of these refugees to be close to 350,000. The Kibaki government took interest in these people and attempted to set in motion a public welfare policy through the development of 443 land distribution programmes. According to the Kibaki administration, 232,225 people would have benefited from these plans. ${ }^{30}$ However, the redistributed land was often in the Rift Valley, which was a major factor behind the tension with the Kalenjin community. This latter considered the measures as a recolonisation of their land reminiscent of the Kenyatta era, during which several Kikuyu families came to this province.

52 A second dynamic is the basis of the rejection ideologies. Towards the end of the 1990s, the East African Tanning Extract Company (EATEC, which for a long time belonged to 
the multinational company, Lonrho) placed back on the market several thousands of hectares of good quality arable land. The State leadership (especially Daniel arap Moi himself) amassed vast tracts of land at a good price. It provoked intense mobilization among the local people and a young generation of politicians, who took the mantle of Nandi nationalism, and who were especially hostile to other Kalenjin sub-groups. ${ }^{31}$ Since then, the other large group belonging to the Kalenjin entity, the Kipsigis, developed their own nationalism. These young politicians, who refer to themselves as "nationalists," conducted an exclusion election campaign, which was a big success and most of them were elected.

The success of reformulating these political identities seems to have crystallized an evolution in the methods of massacres in the Rift Valley. Reports on the investigations on ethnic cleansing in the 1990s show that the killings were perpetrated by gangs sent out to maim and kill. These youths were apparently from outside these areas. In 2008, the local people were involved in the violence. They were called upon to fund the violence and provide young men, notably with the help of pressure from elders. However, evidence of this remains rather incomplete.

Whereas in 1992-1993, violence was confined to the Rift Valley, in 2008, the crisis took a national dimension. Thus, several towns were affected.

\section{Urban violence and killings by the police}

Most of the towns in the country were affected by the election violence in very different ways. Many slum areas were seriously affected by inter-community tension. Urban areas also experienced brutality of the police force which often acted like social actors serving one side. The policemen routinely behaved like faithful and extremely partisan allies of the ruling class. In some regions, however, they did not appear to be State representatives and holders of power. They could therefore openly support the opposition, including when groups perpetrated killings in their name.

Kisumu was one of the towns that was most affected by the election violence. In the days that followed the announcement of election results, Kisumu wrote a new chapter in its political martyrdom. In the Luo capital and the Odinga family stronghold, any impression of stolen victory would have inevitably led to a popular uprising. For forty years, the Luo people had cultivated a strong sense of frustration or persecution. They felt alienated from power but Odinga rekindled a prophetic hope that was magnified by the tribulations. Moreover, as a leader, he has always included the younger generation in his political plans. R. Odinga is one of the very rare Kenyan politicians who considers youth issues and takes them into account. While the political class considers them as social cadets who must submit to the authority of elders and elites, R. Odinga considers the fact that in Kenya's electoral democracy, the youth is an important majority group that always aspires to some autonomy, at least from the elders. Thus, he treats them like a specific entity with whom legitimate dialogue can be engaged. Thus he enjoys enormous popularity among the youth in the Luo community as well as in other communities.

57 As soon as M. Kibaki's re-election was announced, the streets of Kisumu were flooded with crowds that more than ever before needed scapegoats. The small Indian minority, which was deeply engaged in trade and industry, saw their businesses and warehouses looted. However, these families did not feel threatened and, apparently, none of these 
important economic players considered leaving the area or the country. Apart from material damages, these popular protests resulted in many deaths, caused mostly by the police.

During the first wave of violence, the police in Kisumu caused about a hundred deaths, perhaps one of the biggest massacres of the crisis that followed the 2007 elections. It is imperative to see in this the effect of the policy of brutality against the opposition on which the government was quick to apply the infamous "shoot-to-kill" policy. This was typical of the police under the autocratic D. arap Moi era. The repression was bloodier than planned because of the incompetence of the forces sent to Kisumu. The best trained forces ${ }^{32}$ had been confined to Nairobi where the authorities wished to contain the situation and prevent opposition meetings at all costs.

These brutal acts by the police are symptomatic of a force in which most of the officers did not have appropriate training and were assured of absolute impunity. Thus, the Kisumu killings only added itself to the long list of the massacres perpetrated by the police, namely: Garissa (1980), Wagala (1984) where close to 500 Somalis were killed, Madogashe (1982), Bagala (1989), and Malkameri (1996).

Nairobi, the country's capital also experienced several episodes of particularly vicious violence. How did this begin? Is it possible to talk about spontaneous outbreak of armed skirmishes or should specific responsibility be assigned particularly to policemen?

It is even more difficult to know whether personalities, especially elected leaders or elders, caused inter-community tension in some parts of Nairobi. If this is the case, the reasons could be varied. At the national level, opposition leaders played the violence card as a means of forcing the incumbent to negotiate without too much hesitation. This strategy had some effect in the capital city of Kenya to the extent that since the return of the multi-party politics, politicians have used inter-ethnic violence to discipline the middle class and force them not to cut ties with their communities in rural areas. In Nairobi particularly, the middle class districts are too few to cater for the salaried masses that no longer consider themselves as part of the popular classes. Quite often, they live in houses within slum areas where the shacks, cardboard and plastic houses stand alongside very decent houses. All these Nairobi residents, who earn good incomes but could only find accommodation in the slums, were increasingly forced to move to residential areas where their ethnic group is dominant. Ethnic pluralism in the middle class residential areas was not the case in the slums, where it was reduced probably due to ethnic cleansing brought about by the electoral crisis.

It is difficult to blame the massacres in Mathare, Dandora, Kariobangi on politicians alone. The youth militias were also to blame. They were fighting for the control of the lucrative security and ransom market, amongst many other possible rackets. The election crisis made it possible to challenge the hegemony of certain gangs over certain parts or streets of Nairobi. These gangs also used social tension within their areas, especially those described by journalists as the "rent wars." ${ }^{33}$ It was also easy to capitalize on these sentiments because home owners or landlords are mostly Kikuyu while the tenants are generally from other communities.

63 A third social actor played an important role in the Nairobi massacres. Indeed, the police were involved in several excesses like they were in Kisumu. ${ }^{34}$ The violence particularly took place in Kibera, located in the constituency represented by opposition 
leader R. Odinga. The Kenyan police had long forgotten its motto, Utumishi Kwa WoteService to All.

The Nairobi killings essentially took place during the first fifteen days of the crisis. From mid-January, an uneasy calm was apparent. Some militia groups emerged from the tension strengthened, as was the case with Mungiki. After suffering several setbacks and being evicted from some parts of Mathare, the movement was able to rearm, with tacit protection from the police forces, which had hunted them down throughout 2007. This neo-prophetic sect, surviving on its militia activities, sought to resurrect its activities in other Kikuyu towns (particularly Thika and Kiambu) or in towns where Kikuyu are dominant (in eastern parts of the Rift Valley Province). "Between $23^{\text {rd }}$ and $30^{\text {th }}$ January, the Kikuyu militia in the Rift Valley towns-Molo, Naivasha and Nakuru-carried out ethnocide targeting local communities: Luos, Luhya, Kalenjin, and other minority groups associated with ODM and, by extension, with violence against the Kikuyu elsewhere in the country" ${ }^{35}$, the Human Rights Watch report says. Ben Rawlence, the report editor in his document and interviews emphasizes the involvement of Mungiki groups. Numerous rumours circulated that politicians funded the violence and some names were repeatedly mentioned. An example is Samuel Paul Kihara, a former parliamentarian, who is also said to have urged the police in Naivasha to remain passive during the massacres and to stop prison warders from intervening. ${ }^{36}$

Too much blame is perhaps directed towards the Mungiki, which is believed to have been involved in many tension zones during the second wave of violence (from the end of January 2008). Mungiki became a label whose name alone sent shivers down the spine. This organization became the symbol of militia culture that prospered from the privatization of security throughout the country. Mungiki is the most famous militia in the country but it also owes its success to its unique religious nature. ${ }^{37}$ It has assets that could enable it to capitalize most on the post-crisis situation as compared to other groups. This is because the outbreak of violence, which thrust the youth into the limelight, also showed them their capacity to change the situation. Obviously, the issue of youth will be a crucial stake in reconstruction.

\section{Conclusion}

Following the agreement negotiated under Kofi Annan's chairmanship, the violence linked to the electoral crisis seemed to die down. By the end of February, there were still some pockets of tension, mainly on the slopes of Mount Elgon and, more sporadically, in the country's arid areas in the north. In the Mount Elgon region, the establishment took advantage of the recent respite to finally send available troops. The GSU, followed by the army, occupied this region. On the Ugandan side, the army tried to close the border and arrested youths who were then handed over to Kenya. This new understanding between the two countries ${ }^{38}$ temporarily put an end to the excesses perpetrated by the Sabaot Land Defence Forces (SLDF). However, the guerrilla forces remain intact and no political solution has been negotiated yet.

The entire northern Kenya semi-desert area also experienced tension linked to the effects of a persistent drought and a near-famine in several areas. As usual, these economic conditions caused many armed clashes. But in these regions, it was difficult to clearly distinguish the "usual" violence from those linked to the elections. From February 2008, the three Laikipia districts experienced clashes between Kikuyu farmers 
and the groups of Turkana and Tugen pastoralists in search of pasture. However, some quarters believe the theft of livestock had been instigated or funded by politicians trying to incite violence. ${ }^{39}$

Nevertheless, one month after the ceasefire, the situation in Kenyan appeared quiet but certainly not peaceful. The embers will be reactivated if an efficient power-sharing arrangement is not established. However, it has been observed that the two sides have difficulty in coming to an agreement.

There is still no historical perspective to assess the effects of this terrible election violence. What comes out clearly is that the ethno-nationalism of exclusion, that basically seemed confined to the Rift Valley, has pervaded the entire political space in the country. More than ever before, different communities have difficulty in cohabiting within the entire area of Kenya deemed useful, meaning situated above 1500 metres altitude. The idea of a nation has been cracked on all sides and the State has for a long time been disregarded. But the strategy of rigging and violence brings obvious gains, in particular for the top elite. Thus, the Kikuyu oligarchy, previously weakened by the election ${ }^{40}$ emerged from the crisis re-legitimized, at least within its ethnic community.

The situation is such that once the crisis is over Kenya is going to have to negotiate a post-conflict arrangement. The cease-fire agreement already provides for transitional justice measures through a commission charged with an inquiry into how and why the electoral fiasco happened. In addition, a Commission on Justice and Reconciliation will seek to shed light on the post-election violence. These bodies will have difficulty in carrying out their work in a country disillusioned by the systematic use of such expensive commissions, which ultimately have no impact. ${ }^{41}$ Kenyans find it difficult to believe that leaders who perpetrated the massacres will be taken to court. The Kibaki regime has clearly demonstrated that politicians are assured of absolute immunity. This tacit rule even applies to opposition politicians. Without trying to predict the future, one can say that the modalities of transitional justice depend on the nature and form of political transition. The peace agreement provided for the resolution of the crisis through power-sharing. Under these conditions, how can anyone contemplate criminal punishment for political leaders who committed massacres? It is likely that the legal obligation and the memory will be greatly limited as much as possible to enable former enemies to work together.

71 The transitional justice and reparation measures are aimed at dressing wounds but they are not designed to end the causes of conflicts. The Kenyan crisis took the form of eviction of certain communities accused of amassing wealth at the expense of others. President Moi's regime orchestrated (and manipulated) this ideology of exclusion, and at the same time it implemented policies to help communities that were lagging behind to catch up. Thus, a quota policy was practiced in the universities in order to facilitate integration of youth from pastoralist ethnic groups. In the recruitment of civil servants, similar measures were used to ensure equality of chances between ethnic communities. However, these measures were perceived as politics of cronyism and patronage. Nevertheless, many Kenyan and a number of political groups recommended a more equitable distribution of the national cake between the different regions of the country.

72 Certain analysts interpreted the Kenyan crisis as a revolt of the poor against an extremely unequal economic system. It is true that Kenya is one of the countries where social inequalities are highest. 

economic growth in the last few years benefited everyone or just a small privileged minority. The United Nations figures alone show that poverty increased during the last three years of economic growth. Findings by government departments show the opposite: "At the end of April 2007, a joint survey by the government and donors on the conditions of living in the country revealed that levels of poverty had decreased from $56 \%$ to $46 \%$ and were still on a downward trend." 42 Apart from disputes over statistics, opinion polls indicated that a majority of Kenyans felt that their conditions of living had not improved in the last few years. They are especially aware that there is a lack of collective solidarity mechanisms. Families are not a perfect safety net. With the electoral crisis, the ethnic community has once again, become a shield-albeit with imperfections-against aggression by other communities. There is a lack of social security systems. C. Ngilu, Minister of Health during M. Kibaki's first term in office, had recommended a basic health insurance, which ended up being rejected. Kalonzo Musyoka and to a lesser extent, R. Odinga, based their presidential campaign on a development program under a welfare State. The need for social protection was thus at the heart of political debates in which we should see the best of chances for safeguarding Kenyan citizenship.

The Kenyan crisis also brought to the fore a broad range of land issues. Both politicians and analysts persistently recall that Kenyans lack land. However, this thirst for land will never be quenched. Half-hearted land distribution programmes only serve to stir fantasies and frustrations and the legal status of ownership appears more uncertain than ever. Hernando de Soto ${ }^{43}$ obtained instant influential success with his thesis that capitalism has failed outside the West because the right to land ownership is not guaranteed. He says that for development to take place there is need for property rights that will give small entrepreneurs incentives to play in the market. It is especially applicable to the agricultural sector. Property rights would have to be accorded to squatters, or at the very least legalize their status. His approach may appear simplistic but it stresses the need to extend participation in a capitalist system to vast populations. It presupposes fairer market regulation in Kenya. Crony capitalism, which often characterizes economic practices in this country, is probably one of the worst obstacles to equally distributed economic growth. However, streamlining the economy and affirming genuine property rights presupposes a State where there is predictability and far-reaching reforms, especially in the judiciary.

The extremely violent nature of the 2007 elections showed that electoral democracy is still very fragile. Politicians have embraced the values of this type of government with many ulterior motives. It is therefore difficult for them to propose, in good faith, a social contract that will sincerely question the source of its prosperity.

\section{BIBLIOGRAPHY}

APPADURAI, A. (2007). Géographie de la colère. Paris: Payot. 
BADEJO, B.A. (2005). Raila Odinga. An Enigma in Kenyan Politics. Lagos,

Nairobi: Yintab Books.

CHUA, A. (2008). Le monde en feu. Violences sociales et mondialisation. Paris: Seuil.

ELKINS, C. (2005). Imperial Reckoning: The Untold Story of Britain's Gulag in Kenya. New York: Henry Holt, Jonathan Cape.

FUREDI, F. (1989). The Mau Mau War in Perspective. London: James Currey.

GOUX, M.-A. (2003). 'Guerre des loyers dans les bidonvilles de Nairobi.' Politique Africaine, no. 91, pp. 68-82.

KANOGO, T. (1987). Squatters \& the Roots of Mau Mau. Londres: James Currey.

MAUPEU, H. (2002). 'Physiologie d'un massacre: la tuerie du 3 mars 2002, Kariobangi North (Nairobi, Kenya).' Annuaire de l'Afrique Orientale 2002. Paris, Nairobi, Pau: L'Harmattan, IFRA, CREPAO.

KAPLAN, R.D. (2000). The Coming Anarchy. New York: Random House.

KLOPP, J.M. (2002). 'Can Moral Ethnicity Trump Political Tribalism? The Struggle for Land and Nation in Kenya.' African Studies, 61, 2.

MBATARU P., (2003). 'The anatomy of a crisis: Transitional Politics and the Rent Crisis in Nairobi.' Annuaire de l'Afrique Orientale 2003. Paris, Nairobi, Pau: L'Harmattan, IFRA, CREPAO (pp. 189-232).

MBEMBE, A. (2006). 'Nécropolitique.' Raisons Politiques, no. 21.

OUCHO, J.O. (2002). Undercurrents of Ethnic Conflict in Kenya. Leiden: Brill.

SOTO, H. de (2000). Mystery of Capital. Why Capitalism Triumph in the West and Fails Everywhere Else. New York: Bantam Press.

\section{NOTES}

1. Daniel arap Moi regime had tried to evict him from the KANU branch chairmanship in his Othaya Constituency following rigged elections.

2. A. Chua, 2008, p. 22.

3. A. Appadurai, 2007; R.D. Kaplan, 2000.

4. The Rwandan genocide led to a plethora of reactions from academicians but after a long period. The conflits in Sierra Leone or in Liberia also led to rather delayed analyses.

5. 14 January 2008. The sub-title of her article clearly the basis of her criticism of the Western media which depict the violence in the Southern countries: "The exotic African fanatasy depicted by Westerners shows that we have failed to understand the real reasons behind the conflicts in developing countries."

6. Central Depository Unit, Monitoring Election Violence. Final Report of 2002 General Election, Nairobi, 2003, p. 17.

7. Ibid. p. 5.

8. Ibid. p. 17. 
9. According to the $\mathrm{CDU}$, the method of hiring commissioners of the Electoral Commision of Kenya (ECK) (presidential appointment) does not guarantee their independence. Since 1997, political pratice has been that the President consults the opposition so that election Commissioners are considered acceptable by everyone. Kibaki did not respect this recent constitutional tradition. It is now observed that the cheating during vote tallying could not have happened without the complicity of Commissioners. Other ECK employees, casuals hired ahead of elections, also participated in the rigging. As early 2003, the CDU had begun denouncing the abusive tendencies of these people, who are ill-trained and hired through favouritism and nepotism. Anne Cussac revists these practices in a lengthy paper.

10. 'Ethnic woes a legacy of colonialists' power game.' Pambazuka News, 10 January 2008.

11. C. Elkins (2005). For a critic of her methodology and ideology, refer to David Elstein, 'The end of tbe Mau Mau.' The New York Review of Books, 52, 11, 23 June 2005.

12. Michael Holman (2008), 'Kenya: chaos and responsibility,' openDemocracy, 3 January $2008 . \quad$ URL: https://www.opendemocracy.net/en/ where_does_responsibility_for_kenyas_chaos_lie/ [archive].

13. Wanyama Masinde (2008), 'Kenya's trauma, and how to end it,' openDemocracy, 10 January 2008. URL: https://www.opendemocracy.net/en/ kenya_s_trauma_seven_questions/ [archive].

14. Gérard Prunier (2008), 'Kenya : roots of crisis,' openDemocracy, 7 January 2008. URL: https://www.opendemocracy.net/en/kenya_roots_of_crisis/ [archive].

15. Aggrey Omondi (2008), 'Humanizing the roots of the violence in Kenya.' Pambazuka News, 31 January 2008. URL: https://www.pambazuka.org/governance/humanizingroots-violence-kenya [archive].

16. Angelique Haugerud (2008), 'Kenya: spaces of hope.' openDemocracy, 23 January 2008. URL: https://www.opendemocracy.net/en/kenya_spaces_of_hope/ [archive].

17. John Lonsdale (2008), 'Kenya: ethnicity, tribe, and state.' openDemocracy, 17 January 2008. URL: https://www.opendemocracy.net/en/kenya_ethnicity_tribe_and_state/ [archive].

18. International Crisis Group, Kenya in Crisis. Africa Report no. 137, 21 February 2008; Kenya Human Rights Commission, Violating the Vote. A Report on the 2007 General Elections, 27 February 2008; Human Rights Watch, Ballots to Bullets. Organized Political Violence and Kenya's Crisis of Governance, March 2008, Vol. 20, no. 1 (A).

19. B.A. Badejo, 2006 (chap.14).

20. Among the ODM MPs elected in 2007, only two were mentioned in the ethnic killings of the 1990 s.

21. H. Maupeu, 2002.

22. During the colonial era, the best land in the Rift Valley were reserved for Whites. After independence, many British settlers sold their farms, freeing a lot of land in this province considered Kenya's bread basket.

23. Refer in particular to "Still Behaving Badly." Second Periodic Report of the ElectionMonitoring Project, December 2007.

24. J.O. Oucho, 2002.

25. Olenguruone was until 2007 one of the 16 "divisions" of Nakuru District. It was carved administratively out of Molo "Division" but Molo is the undisputed political 
centre of this area. This is, especially due to the fact that it is the big town in this part of the vast Nakuru District (17,188 urban dwellers out of the 31,935 inhabitants of the Molo "Division" compared to only 509 urban dwellers out of 32,030 inhabitants of Olenguruone "Division" source: 1999 Census). It is first and foremost an important administrative center along the Mombasa-Kampala railway. For some months now, Molo has become an autonomous district which includes Olenguruone.

26. Refer to T. Kanogo, 1987 (chap. 4) ; F. Furedi, 1989 (chap. 3), for instance.

27. Any form of cultivation is prohibited in the areas recognized by law as "forest land."

28. The gradual drying up of this lake has been attributed to this deforestation.

29. http://www.unosat.org [Not available. Archive].

30. Internal Displacement Monitoring Centre-Kenya, Continued conflict and displacement in the Rift Valley, Special report, December 2006. Figures provided by the government should be considered with some caution. Indeed, these resettlement programs for the internally displaced particularly enabled Kikuyu tycoons to get rid of their large farms in the Rift Valley and which were for now unprofitable and had lost resale value. Njenga Karume, the defence minister is the first term of the M. Kibaki government, was apparently one of the beneficiaries of this manna.

31. Kalenjin is an amorphous ethnic entity created by Daniel arap Moi and other leaders shortly after the Second World War in progressive preparation for independence. Thus, these Nilotic ethnic groups (principally the Kipsigis, the Nandi, the Tugen, the Keiyo, the Marakwet, the Pokot and the Sabaot) came together to avoid marginalisation in negotiations between ethnic blocs. To read about the political efefcts of the EATEC affair, refer to J.M. Klopp, 2002. This paper demonstrates the positive effects of reinvention of Nandi nationalism. The 2008 massacres reveal the dark side fo this same ideology.

32. GSU (General Service Unit, paramilitary) forces have been trained in Israel and their anti-riot gear has been provided by France.

33. M.A. Goux, 2003 ; P. Mbataru, 2003.

34. Human Rights Watch, Ballots to Bullets, op. cit., pp. 32-35.

35. Ibid., p. 43.

36. The Naivasha prison is one of the leading prisons in the country. There are more than 500 prison warders. During the violence, the prison commandant ordered his troops to take positions in the town. They were shot at by the police. In the interest of calm, the correctional institution officers withdrew from the town and left behind one of the worst massacres of the crisis.

37. For a more detailed analysis of Mungiki politics, refer to my paper in this collection, 'The role of religious institutions.'

38. The Kenyan crisis underlined the Uganda's economic dependence on its neighbour. Y. Museveni was forced to negotiate solutions with the Kenyan leadership that would enable the transportation of goods to the Great Lakes part of Africa to resume quickly despite the number of roadblocks that were erected on the two main roads linking Nairobi and Kampala.

39. Integrated Regional Information Networks (IRIN), 'Kenya: Tracing roots of conflict in Laikipia.' 31 March 2008. 
40. In Central Province, only 8 MPs out of 29 were reelected. Several ministers were sent packing in their constituencies. Kikuyu voters massively voted for the ruling party nomenklatura around the President.

41. After the return of multi-party politics, President Moi appointed commissions on any sensitive matter. The reports were often not released or were released too late, as was the case on the 1992-1993 ethnic massacres or the conclusions of the Kirima Commission on devil warship.

42. Michael Chege, 'Weighed down by old ethnic baggage, Kenya races to another historic election.' Online Africa Policy Forum, 22 June 2007. URL: https://www.csis.org/ analysis/weighed-down-old-ethnic-baggage-kenya-races-another-historic-election [archive]. M. Chege's synthesis of the report does not indicate which period the rate of poverty has decreased from 56 to $46 \%$.

43. H. de Soto, 2000. His theories were acclaimed by a variety of personalities like Margaret Thatcher and Milton Friedman.

\section{AUTHOR}

\section{HERVÉ MAUPEU}

The author a lecturer in Political Science and director of CREPAO (Centre for Studies and Research on East African Countries - Centre d'Étude et de Recherche sur les Pays d'Afrique Orientale, Université de Pau et des Pays de l'Adour). 